\title{
SNOW SURVEY OF THE BRITISH ISLES
}

THis Survey, which, under the directorship of Mr. Gordon Manley, had made substantial progress until the war intervened, is to be resumed during the autumn of 1946 . For a time the principal aim will again be to secure representative data relating to the occurrence of snow-cover at different altitudes in the various upland districts over the period October to June. To this end the Society is fortunate in having already been promised the help not only of a number of pre-war participators in the Survey but also of the Meteorological Office, Air Ministry. By the courtesy of the Director, Sir Nelson Johnson, records of the daily incidence of snow-cover (and where possible of its depth) at about 55 high-level meteorological stations are to be supplied to us month by month. In addition, Dr. J. Glasspoole of the British Climatology Division has suggested that a considerable number of the regular contributors to the official publication British Rainfall whose gauges are situated at altitudes of not less than 500 feet should be invited to co-operate. Dr W. A. Harwood, Superintendent of the Meteorological Office at Edinburgh, has kindly agreed to allow that office to be used as a clearing house for Scottish records, as before the war.

It is particularly hoped that observers may be found who can keep a watchful eye during the summer months on the quasi-permanent snow-beds of the Allt-a-Mhuillin (Ben Nevis) and Braeriach corries, and on the long-surviving drift in the deep gulley beneath the summit of Carnedd Llewelyn. A question to be investigated is whether or not there remain to be discovered other northern hollows that usually or often harbour snow from year's end to year's end. How far this and other objects of the Survey can be covered by sources of information likely to be made available in the near future will be uncertain until the extent of the co-operation forthcoming from the Meteorological Office's corps of rainfall observers is known. Members of the Society will be notified as soon as possible of the localities from which additional data are needed. At a later stage it is intended to follow up a suggestion by the President of the Society that the Survey should include a study of the relationship between the various types of snow crystal and weather conditions.

The reorganization of the Survey is being undertaken for the Society by Mr. E. L. Hawke, Honorary Secretary of the Royal Meteorological Society, 49 Cromwell Road, London, S.W.7. Communications and further offers of help may be sent to Mr. Hawke or to the Assistant Secretary of the British Glaciological Society. The work of direction of the Survey will be shared by Mr. Hawke, Mr. S. E. Ashmore and Mr. D. L. Champion who are members of both Societies.

\section{AVALANCHE RESEARCH}

In the years immediately preceding the war more work on the causes of avalanches was done in Switzerland than in any other country. We in this country were kept well posted in the progress of the work by the willing cooperation of the Swiss and their permission for us to visit their avalanche research station on the Weissfluhjoch.

We have not yet learnt of all the work that has been carried out during the war years, but the impression we have--and we stress that at present it is only an impression-is that the knowledge of the physical condition of snow which causes avalanches is very far advanced; if this is the case further research may perhaps take the form of investigations into the meteorological conditions which bring about the physical changes in the snow.

The Swiss appear also to be turning their attention more and more from the changes of snow in a snowfield to the changes of ice in a glacier-the natural corollary to snow investigations. A similar course was followed by those carrying out snow research in this country.

We hope later to report more fully on progress in snow and ice research abroad. 